\title{
Proses Berpikir Siswa SMA Level Deduksi Informal dalam Menyelesaikan Soal Dimensi Tiga menurut Tahapan Wallas
}

\author{
Author: \\ Ilmi Mamruatul Kharimah ${ }^{1}$ \\ Titik Sugiarti ${ }^{2}$ \\ Susanto ${ }^{3}$ \\ Toto Bara Setiawan ${ }^{4}$ \\ Didik Sugeng Pambudi ${ }^{5}$ \\ Tutut Triningsih ${ }^{6}$

\section{Affiliation:} \\ 1,2,3,4,5 Mathematics Education, \\ University of Jember, East \\ Java, Indonesia. \\ ${ }^{6}$ SMAN 1 Kencong Jember, \\ east Java, Indonesia.
}

\section{Corresponding author:}

Ilmi Mamruatul Kharimah, ilmimamruatulk@gmail.com

\section{Dates:}

Received: 10/5/2021

Accepted: 1/7/2021

Published: 9/7/2021

\begin{abstract}
Abstrak. Geometri merupakan cabang ilmu matematika yang dipelajari siswa. Teori yang mengungkapkan kemampuan dan proses berpikir geometri siswa adalah teori van Hiele dan teori berpikir Jean Piaget. Jenis penelitian yang digunakan adalah penelitian deskriptif kualitatif. Subjek penelitian ini yaitu siswa kelas XII di salah satu SMA Negeri di Kabupaten Jember yang berada pada level deduksi informal. Tujuan dari penelitian ini yaitu untuk menganalisis proses berpikir siswa SMA level deduksi informal dalam menyelesaikan soal dimensi tiga berdasarkan tahapan Wallas. Hasil penelitian ini menunjukkan bahwa siswa pada level deduksi informal dapat memahami informasi terkait apa yang diketahui pada tahap preparasi. Pada tahap inkubasi, siswa pada level deduksi informal membutuhkan waktu untuk menentukan rumus yang tepat. Pada tahap iluminasi, proses berpikir siswa level deduksi informal diawali dengan menyelesaikan soal menggunakan rumus yang diketahui kemudian sebagai bantuan untuk menyelesaikan soal. Pada tahap verivikasi, siswa level deduksi informal memeriksa kembali hasil penyelesaian yang telah dilakukan akan tetapi tidak menuliskan kesimpulan.
\end{abstract}

Kata kunci: Proses Berpikir Geometri, Level Deduksi Informal, Tahapan Wallas.

\begin{abstract}
Geometry is a branch of mathematics learned by students. The theory that expresses students' ability and geometric thinking processes are van Hiele's theory and Jean Piaget's theory of thinking. The research typeis qualitative descriptive research. The subjects of this study were students of class XII SMA in one of the senior high schools in Jember Regency who were at the level of informal deduction. This study aims to analyze the thinking process of high school students at the informal deduction level in solving threedimensional questions based on the Wallas stage. The results of this study show that students at the level of informal deduction can understand information related to what is known from the questions at the preparation stage. At the incubation stage, students at the informal deduction level need time to find the correct formulas. In the illumination stage, the thought process of students at the informal deduction level trying to solve the problem using a known formula which then becomes an aid to solve the problem. At the verification stage, students at the informal deduction level re-examine the results of the completion that has done but do not write down the conclusions.
\end{abstract}

Keywords: Geometric Thinking Process, Level of Informal Deduction, Wallas Stages.

Read online:

https://jurnal.unej.ac.id/index.php/JOMEAL/index

or scan barcode beside.

\section{TON $10 \begin{aligned} & \text { Copyright: } \\ & \text { This work is licensed under a Creative Commons Attribution-ShareAlike } 4.0\end{aligned}$ \\ TON $10 \begin{aligned} & \text { Copyright: } \\ & \text { This work is licensed under a Creative Commons Attribution-ShareAlike } 4.0\end{aligned}$

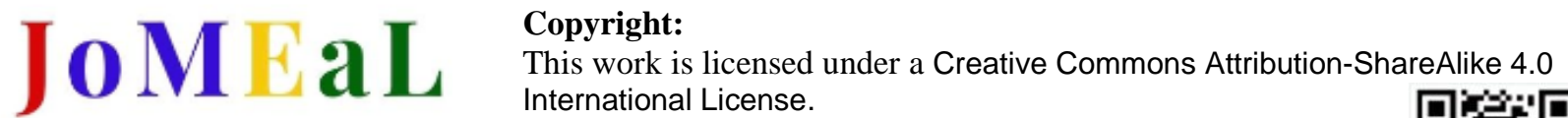

How to cite this article:

Kharimah, I., Sugiarti, T., Susanto, S., Setiawan, T., Pambudi, D., \& Triningsih, T. (2021). Proses Berpikir Siswa SMA Level Deduksi Informal dalam Menyelesaikan Soal Dimensi Tiga menurut Tahapan Wallas. Journal of Mathematics Education and Learning, 1(2), 116-125. Retrieved from https://jurnal.unej.ac.id/index.php/JOMEAL/article/view/24247 


\section{Pendahuluan}

Matematika merupakan mata pelajaran yang wajib diberikan sejak sekolah dasar untuk membekali siswa dengan kemampuan berpikir logis, analitis, sistematis, kritis, inovatif, dan kreatif. Banyak konsep matematika yang dapat dibuktikan atau dijelaskan dengan representasi geometri (Suryana, 2012). Selain dapat menumbuhkankembangkan kemampuan berpikir logis, geometri juga efektif untuk membantu mengerjakan permasalahan dalam banyak cabang matematika (Misri et al, 2013). Geometri adalah bagian dari matematika yang menyelidiki tentang titik, garis, bidang, dan ruang (Bird, 2005). Dalam penerapan pembelajaran matematika, proses berpikir sering kali diabaikan. Hal yang sering dipakai untuk menentukan keberhasilan siswa hanya hasil akhir namun tidak memperhatikan proses penyelesaian yang dilakukan oleh siswa (Muna et al, 2014).

Berdasarkan penelitian yang dilakukan terhadap beberapa siswa SMA, diperoleh fakta bahwa pemahaman konsep-konsep geometri siswa SMA masih rendah khususnya kemampuan menghitung jarak dan sudut antara dua objek (Khotimah, 2013). Kesulitan yang dialami siswa dalam menyelesaikan persoalan dimensi tiga antara lain kesulitan dalam memberikan contoh konsep tertentu, kesulitan dalam memberikan nama bangun ruang, kesulitan dalam klasifikasi, ketidakterampilan siswa dalam keterampilan dasar, kesalahan kalkulasi, kesalahan prosedur, siswa tidak menguasai algoritma dan tidak memahami konsep dasar (Syahrir et al, 2018). Hal ini dikarenakan setiap siswa memiliki cara berpikir yang berbeda-beda dalam menyelesaikan masalah.

Teori yang mengungkapkan kemampuan siswa dalam bidang geometri salah satunya adalah teori van Hiele. Teori van Hiele merupakan hierarki lima level dalam memahami ide dimana setiap level mendeskripsikan proses berpikir, yang digunakan dalam konteks geometri. Terdapat lima level proses berpikir berdasarkan teori van Hiele yaitu level 0 (visualisasi), level 1 (analisis), level 2 (deduksi informal), level 3 (deduksi), dan level 4 (rigor) (Abdussakir, 2009). Masing-masing level tersebut memiliki kriteria yang berbeda-beda.

Deskripsi siswa pada level deduksi informal menurut teori van Hiele antara lain mampu mengidentifikasi hubungan suatu bangun, mampu membuat dan menggunakan definisi, mampu mengidentifikasi suatu bangun, serta mampu menyelesaikan masalah yang menekankan pada pentingnya sifat-sifat gambar (Crowley, 1987). Pada level deduksi informal siswa dianggap mampu untuk merelasikan hubungan antar objek geometri. Berdasarkan hal tersebut dapat diasumsikan bahwa siswa SMA pada level deduksi informal mampu menyelesaikan soal yang melibatkan proyeksi titik dan garis pada bidang dan menentukan penggunaan rumus yang tepat.

Pengidentifikasian proses berpikir siswa dalam menyelesaikan soal dimensi tiga dapat menggunakan konsep berpikir yang dikemukakan oleh Piaget dan tahapan-tahapan yang dideskripsikan oleh Wallas. Jean Piaget adalah salah satu tokoh yang memberikan pengaruh kuat dalam pembahasan mengenai perkembangan kognitif (Khiyarusholeh, 2016). Terdapat empat konsep penting dalam teori Piaget mengenai proses berpikir, yaitu operasi, asilimilasi, akomodasi, dan equilibrasi (Mu'min, 2013; Suparno, 2013).

Penelitian yang relevan dengan penelitian ini adalah penelitin yang dilakukan oleh Razak (2017), yang terfokus untuk menelusuri dan mengklarifikasi jawaban siswa secara mendalam berdasarkan tingkat berpikir menurut teori Van Hiele. Hasil dari penelitian ini menunjukkan bahwa subjek pertama berada pada tingkat analisis, sedangkan subjek kedua berada pada tingkat visualisasi. Disebutkan bahwa siswa pada level deduksi informal mampu mengidentifikasi proyeksi titik pada 
bidang dan garis pada bidang dan dapat memecahkan masalah yang melibatkan proyeksi titik dan garis pada bidang. Penelitian relevan yang lain dilakukan oleh Muslim (2018), dimana Hasil dari penelitian tersebut menyimpulkan bahwa siswa pada level deduksi informal dalam menyelesaikan masalah geometri menggunakan indikator berpikir yang lengkap pada tahap memperoleh informasi, menilai kredibilitas sumber, mendefinisikan istilah yang sesuai. Sedangkan pada indikator lain yaitu mengembangkan masalah, merencanakan percobaan, dan membuat kesimpulan juga ditemukan dari jawaban responden namun tidak lengkap atau tidak sesuai untuk menyelesaikan masalah. Dengan demikian dapat disimpulkan bahwa siswa yang berada pada level deduksi informal menurut van Hiele, dalam menyelesaikan masalah geometri menggunakan proses berpikir yang masih belum sempurna. Berdasarkan uraian tersebut akan dikaji dan dianalisis bagaimana proses berpikir siswa SMA level deduksi informal dalam menyelesaikan soal dimensi tiga berdasarkan tahapan Wallas.

\section{Metode Penelitian}

Penelitian ini merupakan penelitian deskriptif dengan pendekatan kualitatif. Pengambilan data pada penelitian ini dilaksanakan di SMA Negeri 1 Kencong pada tanggal 21 Januari 2021 hingga 6 Februari 2021 dengan subjek penelitian adalah siswa kelas XII yang berada pada level deduksi informal. Pengambilan data dilakukan kepada 57 siswa di kelas XII IPA 1 dan XII IPA 2. Pengambilan data pada penelitian ini menggunakan metode tes dan wawancara. Instrumen yang digunakan dalam penelitian ini antara lain soal tes kemampuan berpikir geometri menurut van Hiele, soal tes dimensi tiga, dan pedoman wawancara. Siswa diberikan tes kemampuan berpikir geometri menurut van Hiele untuk menentukan subjek penelitian. Sebelum digunakan dalam penelitian, dilakukan uji validasi terhadap instrumen soal tes dimensi tiga dan pedoman wawancara dengan hasil perhitungan validasi soal tes dimensi tiga dan pedoman wawancara dipaparkan pada Tabel 1 dan Tabel 2 berikut.

Tabel 1. Hasil Perhitungan Validasi Soal tes Dimensi Tiga

\begin{tabular}{|l|c|c|}
\hline \multicolumn{1}{|c|}{ Aspek yang divalidasi } & \multicolumn{2}{c|}{ Validator } \\
\cline { 2 - 3 } & $\mathbf{1}$ & $\mathbf{2}$ \\
\hline $\begin{array}{l}\text { Permasalahan yang disajikan dapat menggali proses } \\
\text { berpikir siswa dalam menyelesaikan soal dimensi tiga }\end{array}$ & 9 & 9 \\
\hline Soal sesuai dengan indikator & 9 & 8 \\
\hline Soal dapat memenuhi tahapan Wallas & 9 & 10 \\
\hline Bahasa yang digunakan sesuai dengan PUEBI & 8 & 9 \\
\hline $\begin{array}{l}\text { Kalimat pada soal tidak menimbulkan makna ganda } \\
\text { (ambigu) }\end{array}$ & 9 & 8 \\
\hline Petunjuk jelas dan tidak menimbulkan makna ganda & 8 & 8 \\
\hline $\begin{array}{l}\text { Alokasi waktu sesuai dengan jumlah soal yang } \\
\text { diberikan }\end{array}$ & 9 & 9 \\
\hline \multicolumn{1}{|c|}{$V_{(1,2)}$} & 61 & 61 \\
\hline
\end{tabular}

Tabel 2. Hasil Perhitungan Validasi Pedoman Wawancara

\begin{tabular}{|l|c|c|}
\hline \multicolumn{1}{|c|}{ Aspek yang divalidasi } & \multicolumn{2}{|c|}{ Validator } \\
\cline { 2 - 3 } & $\mathbf{1}$ & $\mathbf{2}$ \\
\hline $\begin{array}{l}\text { Pertanyaan pada pedoman wawancara dapat menggali } \\
\text { proses berpikir siswa SMA level deduksi informal } \\
\text { dalam menyelesaikan soal dimensi tiga }\end{array}$ & 9 & 9 \\
\hline
\end{tabular}




\begin{tabular}{|l|c|c|}
\hline \multicolumn{1}{|c|}{ Aspek yang divalidasi } & \multicolumn{2}{c|}{ Validator } \\
\cline { 2 - 3 } & $\mathbf{1}$ & $\mathbf{2}$ \\
\hline $\begin{array}{l}\text { Pertanyaan pada pedoman wawancara dapat dipaparkan } \\
\text { secara singkat dan jelas }\end{array}$ & 10 & 9 \\
\hline Bahasa yang digunakan sesuai dengan PUEBI & 9 & 8 \\
\hline Pertanyaan tidak mengandung makna ganda (ambigu) & 9 & 9 \\
\hline $\begin{array}{l}\text { Pertanyaan komunikatif (menggunakan bahasa } \\
\text { sederhana yang mudah dipahami siswa) }\end{array}$ & 9 & 9 \\
\hline \multicolumn{1}{|c|}{$V_{(1,2)}$} & 46 & 44 \\
\hline
\end{tabular}

Hasil validasi instrumen soal tes dimensi tiga dan pedoman wawancara berturut-turut adalah 8,71 dan 9. Hasil nilai rata-rata validasi yang dilakukan oleh validator menunjukkan tingkat validasi dengan nilai rata-rata lebih dari 6. Hal tersebut menunjukkan bahwa instrumen penelitian dikatakan valid dan dapat digunakan dalam pengambilan data.

Siswa yang menjadi subjek penelitin diberi soal tes dimensi tiga dan dilakukan wawancara. Pada tes kemampuan berpikir geometri van Hiele terdapat 25 soal pilihan ganda tersusun berurutan sesuai dengan tingkatan berpikir van Hiele. Siswa dikatakan mencapai tingkat tertentu pada tingkatan van Hiele apabila siswa tersebut mampu menjawab minimal 3 dari 5 soal yang ada pada setiap tingkatan tertentu dengan benar. Apabila seorang siswa telah gagal pada tingkat tertentu, maka siswa tersebut dianggap gagal pada tingkat berikutnya.

Setelah siswa mengikuti tes kemampuan berpikir geometri van Hiele, siswa dikelompokkan sesuai dengan tingkat kemampuan berpikir geometrinya. Siswa yang berada pada level deduksi informal menjadi subjek penelitian dan diberi soal tes dimensi tiga untuk dianalisis proses berpikirnya berdasarkan indikator proses berpikir menurut Jean Piaget dan tahapan penyelesaian menurut Wallas dan kemudian dilakukan wawancara.

\section{Hasil dan Pembahasan}

Hasil dari penelitian ini yaitu membahas proses berpikir siswa level deduksi informal dalam menyelesaikan soal dimensi tiga menurut tahapan Wallas. Instrumen yang digunakan untuk mengambil data yaitu paket tes kemampuan berpikir geometri van Hiele, soal tes dimensi tiga dan pedoman wawancara.

Setelah instrumen penelitian dinyatakan valid maka tahapan selanjutnya yaitu penentuan subjek penelitian. Pengambilan data dilakukan kepada 57 siswa kelas XII di salah satu SMA Negeri di Kabupaten Jember. Dari 57 siswa yang telah mengerjakan paket soal tes van Hiele menunjukkan bahwa siswa yang berada pada level deduksi informal sebanyak 6 siswa yang kemudian dijadikan sebagai subjek penelitian. Hasil tes van Hiele dapat dilihat pada Tabel 3 berikut.

Tabel 3. Tingkat kemampuan berpikir van Hiele kelas XII SMA Negeri 1 Kencong

\begin{tabular}{|c|c|c|}
\hline Tingkat Berpikir van Hiele & Frekuensi & Persentase \\
\hline Pravisualisasi & 6 & 10,5 \\
\hline Visualisasi & 25 & 43,9 \\
\hline Analisis & 18 & 31,6 \\
\hline Deduksi Informal & 6 & 10,5 \\
\hline
\end{tabular}




\begin{tabular}{|c|c|c|}
\hline Deduksi & 0 & 0 \\
\hline Rigor & 2 & 3,5 \\
\hline
\end{tabular}

Enam siswa yang menjadi subjek penelitian kemudian diberi soal dimensi tiga dan dilakukan wawancara. Enam subjek yang berada pada level deduksi informal diberi kode S1, S2, S3, S4, S5, dan, S6. Data yang dianalisis dalam penelitian ini didapatkan dari hasil soal tes dimensi tiga dan wawancara dari enam subjek penelitian. Hasil wawancara digunakan sebagai penguat dan pendukung analisis data. Berdasarkan hasil soal tes dimensi tiga dan wawancara, didapatkan hasil ketercapaian indikator proses berpikir siswa level deduksi informal dalam menyelesaikan soal dimensi tiga yang disajikan pada Tabel 4 berikut.

Tabel 4. Hasil Ketercapaian Indikator Proses Berpikir Siswa Level Deduksi Informal dalam Menyelesaikan Soal Dimensi Tiga

\begin{tabular}{|c|c|c|c|c|c|c|c|c|}
\hline $\begin{array}{l}\text { Tahapan } \\
\text { Wallas }\end{array}$ & $\begin{array}{c}\text { Proses } \\
\text { Berpikir }\end{array}$ & Indikator & S1 & S2 & S3 & S4 & S5 & S6 \\
\hline \multirow{4}{*}{ Preparasi } & Disequilibrium & $\begin{array}{l}\text { Tidak memahami informasi dari } \\
\text { soal seperti apa yang diketahui dan } \\
\text { apa yang ditanyakan }\end{array}$ & - & - & $\checkmark$ & - & - & - \\
\hline & Asimilasi & $\begin{array}{l}\text { Mampu mengetahui apa yang } \\
\text { diketahui dan apa yang ditanyakan } \\
\text { pada soal }\end{array}$ & $\checkmark$ & $\checkmark$ & $\checkmark$ & $\checkmark$ & $\checkmark$ & $\checkmark$ \\
\hline & Akomodasi & $\begin{array}{l}\text { Mampu mengaitkan informasi dari } \\
\text { yang diketahui dan yang ditanyakan } \\
\text { dari sumber lain }\end{array}$ & - & - & - & - & - & - \\
\hline & Equilibrium & $\begin{array}{l}\text { Mampu mempresentasikan atau } \\
\text { mengutarakan soal dengan } \\
\text { kalimatnya sendiri secara baik dan } \\
\text { jelas }\end{array}$ & $\checkmark$ & $\checkmark$ & $\checkmark$ & $\checkmark$ & $\checkmark$ & $\checkmark$ \\
\hline \multirow{4}{*}{ Inkubasi } & Disequilibrium & $\begin{array}{l}\text { Tidak dapat mengaitkan pertanyaan } \\
\text { dengan materi yang pernah } \\
\text { dipelajari }\end{array}$ & $\checkmark$ & - & - & - & $\checkmark$ & - \\
\hline & Asimilasi & $\begin{array}{l}\text { Mencoba menggunakan semua hal } \\
\text { yang diketahui yang diperoleh dari } \\
\text { soal }\end{array}$ & $\checkmark$ & $\checkmark$ & $\checkmark$ & $\checkmark$ & $\checkmark$ & $\checkmark$ \\
\hline & Akomodasi & $\begin{array}{l}\text { Mencoba menentukan rumus lain } \\
\text { yang akan digunakan dalam } \\
\text { mengerjakan soal }\end{array}$ & - & $\checkmark$ & $\checkmark$ & - & - & - \\
\hline & Equilibrium & $\begin{array}{l}\text { Mampu memilih rumus yang tepat } \\
\text { yang akan digunakan dalam } \\
\text { mengerjakan soal }\end{array}$ & $\checkmark$ & $\checkmark$ & $\checkmark$ & $\checkmark$ & $\checkmark$ & $\checkmark$ \\
\hline \multirow{4}{*}{ Iluminasi } & Disequilibrium & $\begin{array}{l}\text { Mangalami kebingungn saat akan } \\
\text { menyelesaikan soal }\end{array}$ & - & - & - & - & - & - \\
\hline & Asimilasi & $\begin{array}{l}\text { Mencoba mengerjakan soal dengan } \\
\text { menggunakan rumus yang diketahui }\end{array}$ & $\checkmark$ & $\checkmark$ & $\checkmark$ & $\checkmark$ & $\checkmark$ & $\checkmark$ \\
\hline & Akomodasi & $\begin{array}{l}\text { Mampu mengerjakan soal dan } \\
\text { menggunakan rumus yang lain }\end{array}$ & - & $\checkmark$ & $\checkmark$ & - & - & - \\
\hline & Equilibrium & $\begin{array}{l}\text { Mampu memilih rumus yang tepat, } \\
\text { mengkonstruk gambar dan } \\
\text { mengerjakan secara baik dan benar }\end{array}$ & $\checkmark$ & $\checkmark$ & $\checkmark$ & $\checkmark$ & $\checkmark$ & $\checkmark$ \\
\hline Verifikasi & Disequilibrium & $\begin{array}{l}\text { Mengalami kebingungan saat } \\
\text { memeriksa kembali penyelesaian } \\
\text { soal seperti tidak mengerti cara }\end{array}$ & $\checkmark$ & $\checkmark$ & - & $\checkmark$ & $\checkmark$ & - \\
\hline
\end{tabular}


Journal of Mathematics Education and Learning

Kharimah, Sugiarti, Susanto, Setiawan, Pambudi, \& Triningsih

\begin{tabular}{|c|l|l|c|c|c|c|c|c|}
\hline $\begin{array}{c}\text { Tahapan } \\
\text { Wallas }\end{array}$ & \multicolumn{1}{|c|}{$\begin{array}{c}\text { Proses } \\
\text { Berpikir }\end{array}$} & \multicolumn{1}{|c|}{ Indikator } & S1 & S2 & S3 & S4 & S5 & S6 \\
\hline & $\begin{array}{l}\text { memeriksa proses penyelesaian } \\
\text { yang telah dilakukan }\end{array}$ & & & & & & \\
\cline { 2 - 8 } & Asimilasi & $\begin{array}{l}\text { Mencoba memeriksa kembali hasil } \\
\text { dan proses penyelesaian soal }\end{array}$ & $\checkmark$ & $\checkmark$ & $\checkmark$ & - & - & $\checkmark$ \\
\hline & $\begin{array}{l}\text { Mampu memeriksa kembali hasil } \\
\text { dan penyelesaian soal dan } \\
\text { penggunaan rumus-rumus yang } \\
\text { tepat }\end{array}$ & $\checkmark$ & $\checkmark$ & $\checkmark$ & - & - & $\checkmark$ \\
\hline Equilibrium & $\begin{array}{l}\text { Mampu menjelaskan dan } \\
\text { menyimpulkan hasil dan proses } \\
\text { penyelesaian dan menuliskan } \\
\text { kesimpulan dari pertanyaan }\end{array}$ & - & - & $\checkmark$ & - & - & $\checkmark$ \\
\hline
\end{tabular}

Enam subjek penelitian menunjukkan bahwa proses berpikir dalam menyelesaikan soal menurut tahapan Wallas berbeda-beda, tetapi beberapa siswa dengan level tersebut juga mempunyai kecenderungan yang sama dalam menyelesaikan soal. Pada tahap preparasi, semua subjek sempat mengalami kebingungan. Hal tersebut ditunjukkan dengan hasil analisis wawancara yang menunjukkan bahwa mereka membaca soal tidak cukup hanya 1 kali. S1, S2, S4, S5, S6 melalui proses berpikir asimilasi hingga menuju ke proses berpikir equilibrium, sedangkan S3 melalui proses berpikir disequilibrium dikarenakan S3 tidak dapat menuliskan informasi secara lengkap dan juga tidak dapat menyampaikan informasi secara jelas pada saat wawancara. Semua subjek juga mampu menggambar sketsa dari soal dengan benar. Hal tersebut sesuai dengan penelitian yang dilakukan oleh Muhassanah, Sujadi, dan Riyadi yang menyatakan bahwa siswa pada level deduksi informal dapat merumuskan kalimat yang menunjukkan keterkaitan antara bangun segiempat berdasarkan sifat umum yang dimiliki dan mampu membangun gambar (Muhassanah, 2014). Contoh sketsa yang digambar subjek penelitian dapat dilihat pada Gambar 1 dan Gambar 2 di bawah ini.

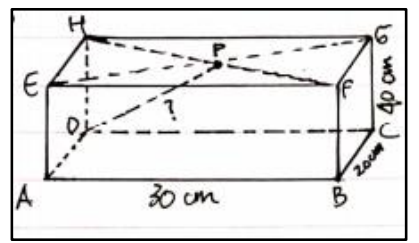

Gambar 1. Hasil sketsa dari soal no 1 oleh S5

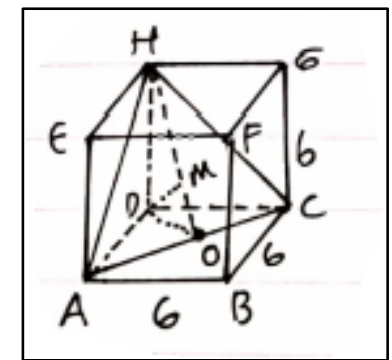

Gambar 2. Hasil sketsa dari soal no 2 oleh S5

Semua subjek menyampaikan bahwa mereka sangat perlu untuk menggambar agar lebih mudah dalam menyelesaikan soal. Salah satu bukti yang menunjukkan hal tersebut dipaparkan pada cuplikan wawancara berikut 
$\mathrm{P} \quad$ : Apakah kamu mencoba menggambar sketsa dari soal?

S3 : Iya

$\mathrm{P} \quad$ : Menurutmu, perlukah menggambar sketsa dari soal tersebut?

S3 : Perlu

$\mathrm{P} \quad$ : Alasannya apa? Kenapa kok perlu menggambar?

S3 : Supaya lebih mudah untuk mengerjakannya

S1, S2, S4, S5, dan S6 dapat dikatakan mencapai proses berpikir equilibrium karena mampu menuliskan informasi dari soal serta mampu menyampaikan kembali secara baik dan jelas. Semua subjek juga mampu menggambar sketsa dari soal dengan benar. Semua subjek menyampaikan bahwa mereka sangat perlu untuk menggambar agar lebih mudah dalam menyelesaikan soal. Hal tersebut sesuai dengan penelitian sebelumnya yang menyatakan bahwa siswa pada level deduksi informal dalam menyelesaikan masalah geometri menggunakan indikator berpikir yang lengkap pada tahap memperoleh informasi, menilai kredibilitas sumber, mendefinisikan istilah yang sesuai (Muslim, 2017).

Pada tahap inkubasi, S2, S3, S4, dan S6 mampu menentukan tahapan menyelesaian yang akan digunakan untuk menyelesaiann soal yang disajikan. S2 dan S3 menggunakan pengetahuan yang mereka miliki sebelumnya. S2 dan S3 memanfaatkan pengetahuan mengenai rumus cepat untuk menghitung jarak dari titik ke bidang yaitu dengan cara $\frac{1}{3} \times$ diagonal ruang sehingga dapat disimpulkan bahwa S2 dan S3 melalui proses berpikir asimilasi dan akomodasi hingga mencapai equilibrium. S4 dan S6 menggunakan rumus Pythagoras sehingga dapat disimpulkan S4 dan S6 melalui proses berpikir asimilasi kemudian equilibrium. S1 dan S5 masih mengalami kebingungan dalam menentukan tahapan penyelesaian atau menentukan rumus yang akan digunakan sehingga $\mathrm{S} 1$ dan S5 mengalami disequlibrum. Dengan demikian S2, S3, S4, dan S6 mengalami peristiwa equilibrium. Berikut bukti cuplikan wawancara yang menunjukkan hal tersebut.

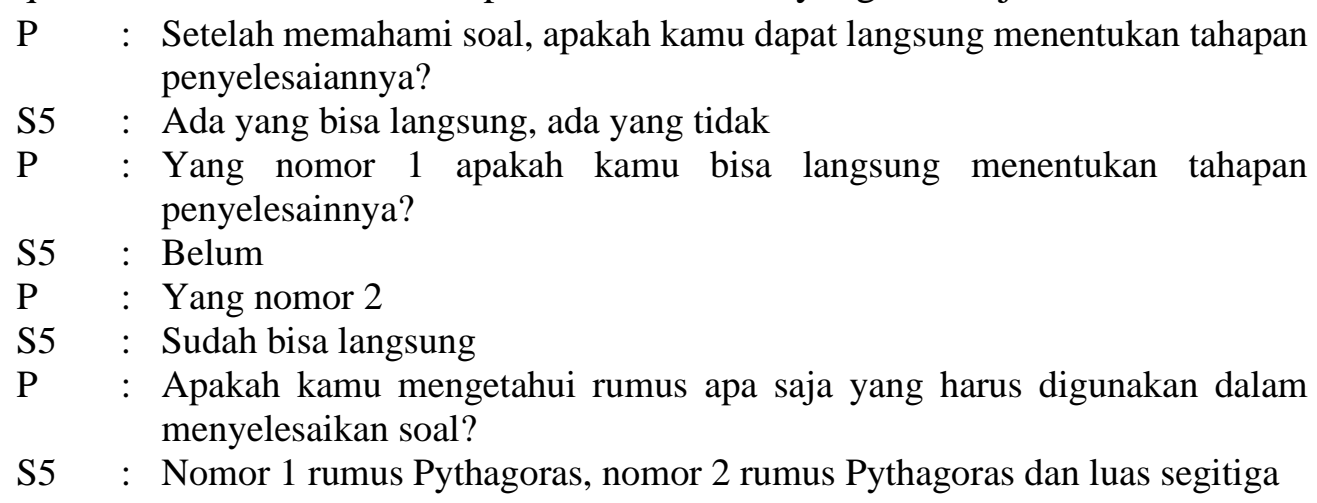

S1 dan S5 mengalami tahap disequilibrium ketika mengalami kebingungan, namun S1 dan S5 terus melakukan proses asimilasi hingga S1 dan S5 berada pada proses berpikir equilibrium dalam tahap inkubasi.

Tahap Iluminasi merupakan tahapan pemecahan masalah. Pada tahap ini, subjek mengalami peristiwa asimilasi dan akomodasi secara terus-menerus. Mereka mencoba menyelesaikan soal yang disajikan dengan melibatkan kemampuan yang telah dimiliki sebelumnya dan menggunakan rumus yang sudah ditentukan pada tahap inkubasi. S2 dan S3 menggunakan cara yang berbeda dalam menyelesaikan soal. Berdasarkan pengetahuan yang mereka miliki sebelumnya, S2 dan S3 mampu menggunakan cara lain yaitu dengan menggunakan rumus $\frac{1}{3} \times$ diagonal ruang dalam menentukan jarak titik terhadap bidang. Namun rumus tersebut hanya berlaku pada bangun tertentu seperti kubus. 
Berdasarkan pengetahuan yang dimiliki S2 dan S3 dapat disimpulkan bahwa S2 dan S3 melalui proses berpikir asimilasi, akomodasi hingga mencapai equilibrium. Berikut jawaban dari S2 dalam menyelesaikan soal nomor 2 .

$\begin{aligned} \text { DACH } & =\frac{1}{3} \cdot \text { druang } \\ & =\frac{1}{3} \cdot a \sqrt{3} \\ & =\frac{1}{3} \cdot 6 \sqrt{3} \\ & =2 \sqrt{3} \mathrm{~cm}\end{aligned}$

Gambar 3. Hasil Penyelesaian Soal Nomor 2 Oleh S2

S1, S4, S5, dan S6 menggunakan teorema Pythagoras untuk menyelesaikan soal. Berikut jawaban dari S1 dalam menyelesaikan soal nomor 2.

\begin{tabular}{|c|c|}
\hline$H O=\sqrt{D O^{2}+D H^{2}}$ & $L_{\Delta}=\iota_{\Delta}$ \\
\hline$=\sqrt{(3 \sqrt{2})^{2}+6^{2}}$ & $a \times t=a \times t$ \\
\hline$=\sqrt{18+36}$ & $\bar{x}$ \\
\hline$=\sqrt{54}$ & $a \times t=a \times t$ \\
\hline \multirow[t]{4}{*}{$\mathrm{HO}=3 \sqrt{6} / 1$} & $D O \times H D=H O X M D$ \\
\hline & $\not \sqrt{2} \times 6=\not 3 \sqrt{\beta} \times M D$ \\
\hline & $6=\sqrt{3} \mathrm{MO}$ \\
\hline & $M D=\frac{6}{\sqrt{3}}=2 \sqrt{3}$ \\
\hline
\end{tabular}

Gambar 4. Hasil Penyelesaian Soal Nomor 2 Oleh S1

S1, S4, S5, dan S6 melalui proses berpikir asimilasi yang berlangsung secara terus menerus hingga semuanya mampu menyelesaikan soal yang disajikan dan berada pada proses berpikir equilibrium. Hal tersebut sesuai dengan penelitian yang dilakukan oleh Razak (2017) yang menyatakan bahwa siswa pada level deduksi informal dapat memecahkan masalah yang melinatkan proyeksi titik dan garis pada bidang. Namun sedikit berbeda dengan hasil yang ditunjukkan pada penelitian ini, yaitu siswa pada level deduksi informal mampu menggunakan penyelesaian masalah yang lebih padat dan ringkas jika dibandingkan dengan proses penyelesaian yang runtut dan sistematis.

Pada tahap terakhir yaitu tahap verifikasi yaitu menguji dan memeriksa kembali hasil penyelesaian soal. S1, S2, S3, dan S6 memeriksa kembali hasil penyelesaian dengan menghitung kembali. S3 dan S6 mampu menjelaskan dan menyampaikan kesimpulan dari pertanyaan pada saat wawancara. Hal tersebut mengindikasikan bahwa S3 dan S6 mengalami peristiwa equilibrium sesuai dengan indikator penelitian. Berikut cuplikan wawancara yang menunjukkan bahwa S3 dan S6 mampu menyampaikan kesimpulan dengan benar.

P : Apakah kamu menuliskan kesimpulan dari hasil penyelesaianmu?

S6 : Tidak

$\mathrm{P} \quad$ : Kenapa tidak menuliskan kesimpulan?

S6 : Karena kebiasaan tidak menuliskan

$\mathrm{P} \quad$ : Coba disampaikan kesimpulan nomor 1 gimana

S6 : Jarak titik D ke titik P sama dengan $10 \sqrt{29}$

$\mathrm{P}$ : Yang nomor 2 coba kesimpulannya bagaimana?

S6 : Jarak titik D ke bidang ACH sama dengan $2 \sqrt{3}$ 
S1, S2, S4 dan S5 tidak melakukan pemeriksaan kembali dan juga tidak menuliskan kesimpulan dari pertanyaan. Hal tersebut berarti S1, S2, S4 dan S5 mengalami peristiwa disequilibrium karena tidak memeriksa kembali serta tidak menuliskan dan menyampaikan kesimpulan berdasarkan indikator penelitian yang sudah ditentukan. Hal tersebut sesuai dengan penelitian yang dilakukan oleh Muslim (2018) yang menyimpulkan bahwa siswa yang berada pada level deduksi informal menurut van Hiele, dalam menyelesaikan masalah geometri menggunakan proses berpikir yang masih belum sempurna.

\section{Kesimpulan}

Berdasarkan hasil analisis data dan pembahasan terhadap penyelesaiaan dari keenam subjek penelitian dapat disimpulkan bahwa siswa pada level deduksi informal memiliki kecenderungan melalui semua tahapan penyelesaian Wallas yang meliputi tahap preparasi, tahap inkubasi, tahap iluminasi, dan tahap verifikasi. Masing-masing subjek memiliki ketercapaian indikator proses berpikir yang berbeda-beda. Pada tahap preparasi, 5 subjek penelitian langsung mencapai proses berpikir asimilasi sedangkan 1 subjek melalui disequilibrium. Siswa pada level deduksi informal cenderung dapat memahami informasi terkait apa yang diketahui dan apa yang ditanyakan dari soal dan mampu mengkonstruk sketsa dari soal pada tahap preparasi. Siswa pada level deduksi informal juga dapat mengutarakan kembali infromasi yang didapatkan dengan kalimatnya sendiri secara baik dan jelas. Pada tahap preparasi, siswa pada level deduksi informal juga mampu mengkonstruk sketsa dari soal dengan benar. Pada tahap inkubasi, siswa pada level deduksi informal cenderung membutuhkan waktu untuk menentukan rumus yang akan digunakan dalam menyelesaikan soal dan melakukan aktivitas mencoba-coba menentukan rumus yang tepat berdasarkan pengetahuan yang dimiliki sebelumnya. 2 subjek penelitian melalui proses berpikir asimilasi dan akomodasi hingga mencapai equilibrium, sedangkan 4 subjek lainnya melalui proses berpikir disequilibrium, asimilasi dan langsung mencapai equilibrium.

Pada tahap iluminasi, proses berpikir siswa level deduksi informal diawali dengan mencoba menyelesaikan soal menggunakan rumus yang diketahui yaitu menggunakan rumus Pythagoras. Hasil dari penyelesaian menggunakan rumus Pythagoras ini kemudian menjadi bantuan untuk menyelesaikan soal sesuai dengan apa yang ditanyakan. 4 subjek yang menggunakan rumus Pythagoras melalui proses berpikir asimilasi dan langsung mencapai equilibrium, sedangkan 2 subjek yang menggunakan rumus cepat melalui proses berpikir asimilasi dan akomodasi hingga mencapai equilibrium. Pada tahap verivikasi, siswa level deduksi informal cenderung memeriksa kembali hasil penyelesaian yang telah dilakukan akan tetapi tidak menuliskan kesimpulan dari soal yang telah diselesaikan. Terdapat 2 subjek yang mengalami disequilibrium, 2 subjek melalui proses berpikir asimilasi dan akomodasi, dan 2 subjek mencapai equilibrium. Kurangnya pemahaman dalam langkahlangkah penyelesaian soal menyebabkan siswa tidak menuliskan kesimpulan dari soal yang diberikan. Namun beberapa siswa mampu menyampaikan kembali hasil penyelesaiannya dengan baik dan jelas.

\section{Daftar Pustaka}

Abdussakir. (2009). Pembelajaran geometri sesuai teori van Hiele. Jurnal Pendidikan Matematika, - . Bird, J. (2005). Basic Engineering Mathematics. Routledge.

Crowley, M. L. (1987). The van hiele model of the geometric thought dalam linquist,M M(eds) Learning and Teaching Geometry. Viriginia: The NCTM,Inc. 
Khiyarusholeh, U. (2016). Konsep dasar perkembangan kognitif pada anak menurut Jean Piaget. Jurnal Dialektika PGSD, 5.

Khotimah, H. (2013). Meningkatkan hasil belajar geometri dengan teori van Hiele., (pp. 978-980).

Misri, M. A., \& Zhumni, A. I. (2013). Pengaruh tingkat berpikir geometri (teori van hiele) terhadap kemampuan berpikir siswa dalam mengerjakan soal pada materi garis dan sudut. Jurnal Pendidikan Matematika, -.

Muhassanah, N., Sujadi, I., \& Riyadi. (2014). Analisis keterampilan geometri siswa dalam memecahkan masalah geometri berdasarkan tingkat berpikir van Hiele. Jurnal ELektronik Pembelajaran Matematika, 54-66.

Mu'min, S. A. (2013). Toeri Perkembangan Kognitif Jean Piaget. Jurnal Al-Ta'dib, 94.

Muna, I., \& Mubarokah, L. (2014). Proses berpikir siswa climber dalam pemecahan masalah matematika pada Sekolah Menengah Atas. Jurnal Pendidikan Matematika, 143-150.

Muslim, A. (2017). Proses berpikir kritis siswa pada level deduksi informal van Hiele. Prosiding Seminar Nasional Integrasi Matematika dan Nilai Islami (pp. 86-94). Malang: Universitas Muhammadiyah Malang.

Razak, F., Sutrisno, A. B., \& Immawan, A. Z. (n.d.). Analisis tingkat berpikir siswa berdasarkan teori van Hiele. Prosiding Seminar Nasional (pp. 75-83). STKIP Andi Matappa.

Suparno, P. (2013). Teori Perkembangan Kognitif Jean Piaget. Penerbit Kanisius.

Suryana, A. (2012). Kemampuan berpikir matematis tingkat lanjut (Advanced Methematical Thingking). Seminat Nasional Matematika dan Pendidikan Matematika FMIPA UNY (pp. 3748). Jakarta: Universitas Indraprasta PGRI Jakarta.

Syahrir, Kusnadin, \& Nurhayati. (2018). Analisis kesulitan pemahaman konsep dan prinsip materi pokok dimensi tiga siswa kelas XI SMK Keperawatan Yahya Bima. Jurnal Prisma Sains, 89103. 